\title{
PROFESOR JANUSZ TAZBIR (5 VIII 1927 - 3 V 2016)
}

DOI: $10.15290 /$ sp.2016.24.19

Z ogromnym żalem przychodzi mi pisać ten nekrolog. Odszedł od nas jeden z najwybitniejszych polskich historyków i humanistów, badacz dziejów kultury staropolskiej, reformacji i kontrreformacji w Polsce i Europie, obdarzony ogromnym talentem pisarskim, niezwykłą erudycją, niespotykaną intuicją badawczą, a przy tym Człowiek o niepospolitym poczuciu humoru oraz pogodzie ducha. Polscy historycy i humaniści ponieśli wielką stratę.

Profesor Janusz Tazbir urodził się 5 sierpnia 1927 roku w Kałuszynie w województwie siedleckim. Opisał to miasteczko swego pogodnego dzieciństwa we wspomnieniach O Kałuszynie, Żydach $i$ - sitarzach w książce Długi romans z muza Klio ${ }^{1}$.

Moje pogodne na ogół wspomnienia historia zamknęła tragicznym akcentem. Wakacji roku 1939 już nie spędzałem w Kałuszynie. Przyjechałem tam z matką 4 września tego roku, aby, jak się okazało być świadkiem słynnej bitwy o Kałuszyn, jaka rozgorzała tydzień później².

Profesor Tazbir w czerwcu 1939 roku uzyskał świadectwo ukończenia piątej klasy w Łomży, do której przeniósł się wraz z rodzicami, matką Władysławą z Żakowskich (1897-1982) oraz ojcem Adamem (1902-1973) w marcu tamtego, pamiętnego roku. W czasie wojny Profesor Tazbir wraz z rodzicami, a po aresztowaniu ojca $\mathrm{z}$ matką znajdowali schronienie poza Łomżą, w Białej Podlaskiej, w Pawłowie, w pobliżu Janowa Podlaskiego, w Wólce Kałuskiej. Powrót w październiku do Łomży zrobił na młodym Profesorze przygnębiające wrażenia. Granica przebiegała pomiędzy okupacjami, niemiecką

1 J. Tazbir, Dtugi romans z muzq Klio, Warszawa 2007, s. 11-27.

2 Tamże, s. 26. 
i sowiecką Notował swe obserwacje w pamiętniczku, diariuszu, z którego korzystał w późniejszych wspomnieniach:

Pod drodze największe wrażenie zrobił na mnie spalony Zambrów z jeszcze dymiącymi zgliszczami. Po dziś dzień, kiedy przejeżdżam przez to pięknie odbudowane miasto, czuję ten właśnie zapach. Bardziej jednak wstrząsnął mnie swym widokiem Czerwony Bór. „Pełno grobów i okopów i wyrw od kul” - zapisałem $\mathrm{w}$ dzienniczku. Po lesie walały się papiery, porzucone najwyraźniej w wielkim pospiechu, bo niektóre z pieczątkami „Ściśle tajne”. Przyszły historyk mógł to ad oculos zobaczyć, jak umierała II Rzeczpospolita ${ }^{3}$.

W swych wspomnieniach opisuje Łomżę tamtego okresu, atmosferę powyborczą, kiedy to jej mieszkańcy dowiedzieli się, że ponad "90\%" miało opowiedzieć się za trwałym pozostaniem w Związku Radzieckim, okres pierwszych wielkich wywózek do Kazachstanu, szkołę, do której powrócił, a w której obowiązywały sowieckie programy nauczania. Wspomina swego ojca, który za "kontrrewolucyjną propagandę" otrzymał osiem lat łagru, uwolniony został wcześniej na mocy paktu Sikorski-Stalin, ale do Polski powrócił dopiero w 1971 roku.

Wraz z matką Profesor uchronili się przed kolejna masową wywózką, dzięki ucieczce w kwietniu 1940 roku do Choroszczy. Tam w latach 1940-1941 Profesor Tazbir uczęszczał do „radzieckiej niepełnej szkoły średniej z językiem polskim”. Jak pisał we wspomnieniach: „prawo Archimedesa pamiętam do dziś po rosyjsku" ${ }^{4}$. W roku 1942 znowu trzeba było uciekać, w obawie tym razem przed wywiezieniem na roboty przymusowe do Prus. Jesienią tego roku Profesor musiał podjąć pracę zarobkową jako tak zwany Gutsschreiber (pisarz majątkowy) w Józefinie pod Łapami. Jak przyznaje Profesor Tazbir na kartach wspomnień, tego typu źródła, jakim były rejestry gospodarcze "usposobiły mnie nieufnie” do nich. Dlatego na uniwersytecie wybrał historię kultury oraz obyczajów, a także dzieje ruchów wyznaniowych.

W 1945 roku rodzina przeniosła się z Białegostoku do Warszawy. W roku 1947 ukończył Profesor VII Liceum Ogólnokształcące im. Juliusza Słowackiego i podjął studia historyczne na Wydziale Humanistycznym Uniwersytetu Warszawskiego:

Interesowała mnie zawsze przeszłość, a w niej ludzie; ich poglądy na wcześniejsze stulecia, wierzenia i obyczaje. Po latach myślę sobie, że gdybym wybrał inny

3 Tamże, s. 31.

4 Tamże, s. 37. 
kierunek studiów, w rodzaju prawa, polonistyki czy nawet teologii, to i tak pisywałbym o dawnych wiekach, a więc odpowiednio o przemianach ustrojowych Rzeczypospolitej, literaturze staropolskiej czy dziejach szeroko pojętego chrześcijaństwa, od katolicyzmu po arianizm. To zauroczenie historią mam widocznie w genach ${ }^{5}$.

Jak sam pisał, zainteresowanie przeszłością zaczęło się jeszcze przed wybuchem drugiej wojny światowej, od lektury powieści historycznych Henryka Sienkiewicza, Józefa Ignacego Kraszewskiego, Zofii Kossak-Szczuckiej, Aleksandra Dumasa, Waltera Scotta i wielu innych.

Ulubionym autorem Profesora był Tadeusz Boy-Żeleński, do którego powracał w swej twórczości, a także cytował z pamięci przy wielu okazjach jego Słówka i inne fragmenty utworów.

Zainteresowania Profesora Tazbira literatura piękną towarzyszyły $\mathrm{Mu}$ przez cale życie i zaowocowały wieloma publikacjami; wymienić wypadnie z pewnością: Od Haura do Isaury. Szkice o literaturze (Warszawa 1989), czy piaty tom Pism wybranych (Szkice o literaturze i sztuce, Kraków 2002).

Magisterium uzyskał Profesor Janusz Tazbir w roku 1950 w Instytucie Historycznym UW, cztery lata później stopień doktorki (kandydata nauk historycznych) pod kierunkiem Władysława Tomkiewicza. Pierwsza praca dotyczyła ksenofobii w Polsce w XVI i XVII wieku, druga - problemu reformacji i stosunku tego ruchu do chłopów.

W listopadzie 1953 roku Profesor musiał odejść z Uniwersytetu do Instytutu Historii PAN. Jak sam pisze:

Zmiana miejsca pracy miała kilka przyczyn: brak zdolności i zamiłowań do prowadzenia zajęć dydaktycznych oraz niechęć do stania się członkiem Związku Młodzieży Polskiej, co wówczas stanowiło prawie że conditio sine qua non dalszego awansu naukowego. Aby do tego zachęcić zapraszano mnie na zebrania ZMP poświęcone właśnie przyjmowaniu nowych członków. Sam pamiętam, w jakich warunkach w Łomży wywożono w lutym 1940 roku między innymi służbę leśną. Przypomnę, był trzaskający mróz i wielu deportowanych, zwłaszcza dzieci, zwyczajnie zamarzło. Traf chciał, że jeden z przyjmowanych, był syn leśniczego, który musiał publicznie uznać deportację za słuszną, a swojego ojca za bezlitosnego ciemiężcę chłopów kłusowników. Uświadomiłem sobie, iż podobny akt skruchy musiałbym wykonać i ja, jako syn żołnierza armii Andersa, który pozostał na emigracji. Nie taiłem przy tym faktu, iż utrzymuję z nim stałą korespondencję ${ }^{6}$.

5 Tamże, s. 57-58.

6 Tamże, s. 61. 
W roku 1969 habilitował się Profesor w Instytucie Historii PAN na podstawie pracy poświęconej Stanisławowi Lubienieckiemu (1623-1675), socyniańskiemu historykowi i astronomowi. Stopień profesora nadzwyczajnego uzyskał w roku 1966. Dzięki dłuższemu pobytowi w Rumunii, powstała książka o pobycie braci polskich w Siedmiogrodzie (1660-1784), późniejsza kwerenda źródłowa objęła również inne ośrodki diaspory ariańskiej, przede wszystkim z Niderlandów i Niemiec.

W roku 1973 został Janusz Tazbir profesorem zwyczajnym. W Instytucie Historii PAN w Warszawie pracował do 1997 roku, sprawując funkcje zastępcy dyrektora w latach 1968-1983, dyrektora w latach 1983-1990. W latach 1973-1983 kierował w Instytucie Zakładem Historii Kultury.

W latach 1999-2003 był wiceprezesem PAN, był także jego członkiem, korespondentem od 1983, rzeczywistym od 1989. Był czynnym członkiem PAU (Polskiej Akademii Umiejętności) i członkiem Komitetu Nauk Historycznych PAN.

W 1965 roku został redaktorem naczelnym rocznika "Odrodzenie i Reformacja w Polsce". Był przewodniczącym Rady Naukowej Polskiego Słownika Biograficznego, przewodniczącym Centralnej Komisji do spraw Stopni i Tytułów. Był członkiem Stowarzyszenia Pisarzy Polskich oraz prestiżowych gremiów naukowych, miedzy innymi Nagrody Naukowej KLIO (członek jury od 1996 roku). Przewodniczył kapitule Konkursu o Nagrodę i Medal Zygmunta Glogera, od 1984 roku prowadzonego przez Społeczne Stowarzyszenie Prasoznawcze „Stopka” z Łomży ${ }^{7}$.

Miał Profesor spory dystans do sprawowanych przez siebie funkcji. Oto, co napisał na ten temat:

Zdaję sobie sprawę, że sporo godzin spędziłem w życiu bez większego pożytku. Mam tu na myśli udział w licznych zebraniach, na których musiałem bywać najpierw jako członek dyrekcji Instytutu Historii PAN, a następnie jako przewodniczący Wydziału Nauk Społecznych tejże Akademii (w latach 1998-2002 zaś jej wiceprezes) ${ }^{8}$.

Profesor Janusz Tazbir, wspaniały znawca dziejów kultury, podziwiany w Polsce i poza jej granicami pozostawił po sobie tak bogaty i różnorodny dorobek naukowy i popularyzatorski, iż omówienie go w jednym wspomnieniu - nie jest absolutnie możliwe. Otrzymał od swych przyjaciół, uczniów

7 Wikipedia encyklopedia: https://pl.wikipedia.org/wiki/Janusz_Tazbir [27.09.2016].

8 J. Tazbir, dz. cyt., s. 76. 
i kolegów dwie Księgi Jubileuszowe, w których na wstępie zawarta jest bibliografia prac Profesora. Szacować można tę liczbę publikacji na ponad tysiąc. Pierwsza Księga zatytułowana Kultura polska a kultura europejska wręczona została Profesorowi w sześćdziesiątą rocznicę urodzin (PWN, Warszawa 1987) i zwiera między innymi artykuły dotyczące kultury politycznej, literatury filozofii i nauki, spraw herezji i różnowierstwa piór tak wybitnych uczonych, jak: Henryk Samsonowicz, Andrzej Wyczański, Bronisław Geremek, Zbigniew Ogonowski, Mariusz Karpowicz, Jerzy Kłoczowski, Jerzy Michalski i wielu innych ${ }^{9}$.

Druga Księga ukazała się pod następującym tytułem: Kultura staropolska - kultura europejska ${ }^{10}$. Księga zawiera artykuły 60 autorów, rozpoczyna Michał Głowiński Dniem Ulissesa, kończy Andrzej Wyczański artykułem Między kształceniem umystu a zbawieniem duszy. Każdy z autorów, jak to zwykle bywa przy okazji ksiąg jubileuszowych, starał się nawiązywać do tematów, którymi interesował się Profesor Tazbir. A obszar zainteresowań Profesora jest imponujący. W latach 2000-2002 dzięki Wydawnictwu Universitas ukazały się w pięciu tomach Prace wybrane: Państwo bez stosów i inne szkice, Okrucieństwo w nowożytnej Europie, Sarmaci i świat, Studia nad kultura staropolska, Szkice o literaturze i sztuce ${ }^{11}$.

Otwiera tę edycję najsłynniejsza książka Profesora Państwo bez stosów. Pierwszy raz ukazała się w Wydawnictwie Iskry w roku 1967, w 1973 w wersji anglojęzycznej, dzięki temu dyskutowana jest do dziś na uniwersytetach w świecie. Zdarza się, iż przyjmuje się, że termin „państwo bez stosów” powstał właśnie w XVI czy XVII wieku i tak charakteryzuje się Pierwszą Rzeczypospolitą jako państwo wyróżniające się pokojowym stosunkiem do różnowierców w Europie gorejącej w ogniu walk religijnych. Tolerancja wyznaniowa była $\mathrm{w}$ tamtych wiekach tak powszechna w Polsce, że żaden (czy prawie żaden) stos nie zapłonął z powodów religijnych ${ }^{12}$. Znaczenie tej

9 Bibliografia publikacji Janusza Tazbira za lata 1949-1986 w: Kultura polska a kultura europejska, red. M. Bogucka i J. Kowecki, Warszawa 1987, s. 5-52 (711 pozycji).

10 Kultura staropolska - kultura europejska, red. S. Bylina et al., Warszawa 1997; tamże, Bibliografia publikacji Janusza Tazbira 1987 - czerwiec 1997, s. 8-18 (222 pozycje).

11 J. Tazbir, Prace wybrane: Państwo bez stosów i inne szkice, Okrucieństwo w nowożytnej Europie, Sarmaci i świat, Studia nad kultura staropolska, Szkice o literaturze i sztuce, red. S. Grzybowski, Kraków 2000-2002, t. 1-5, seria: Klasycy Współczesnej Polskiej Myśli Humanistycznej, red. A. Nowakowski.

12 T. Chynczewska-Hennel, Rzeczpospolita i świat, "Przegląd Humanistyczny” 2004, nr 6, s. 123-135; S. Grzybowski, Janusza Tazbira osobowość i twórczość, [w:] J. Tazbir, Prace wybrane, t. 1, s. V-XXVIII. 
książki jest ogromne. Najlepiej scharakteryzował to Stanisław Grzybowski, zastrzegając, że jednak jakieś nieliczne stosy zapłonęły (na przykład w konsekwencji pomówień o mord rytualny):

Istotnym jednak był fakt, że to połączenie [mowa o nowatorskich prądach metodologicznych - T. Ch.-H.] tradycyjnych wzorów z nowoczesnym ujęciem służyć miało rehabilitacji naszych przodków w czasie, gdy opluwanie nie tylko polskich narodowych tradycji uważano za "postępowe”, a na wszelkie próby ich obrony patrzono podejrzliwie ${ }^{13}$.

Janusz Tazbir dokonywał nie tylko rehabilitacji, lecz także czegoś znacznie większego - przynosił czytelnikowi poczucie dumy z dokonań mądrych Polaków i wszystkich uczestników życia politycznego Pierwszej Rzeczypospolitej nie tylko przecież Dwojga Narodów.

W książce Autor ukazał zjawisko polskiej tolerancji w XVI i XVII wieku w szerokim tego słowa znaczeniu, ponieważ tolerancja obejmowała zarówno publiczno-prawną stronę życia, jak i sferę prywatną. Władzy nie wolno było skłaniać ogniem i mieczem, więzieniem ludzkich sumień do uległości wobec panującego Kościoła i władzy świeckiej.

Szlachta zebrana w Warszawie 28 stycznia 1573 roku spisała akt konfederacji. Uczestnicy konfederacji warszawskiej zobowiązali się $\mathrm{w}$ imieniu własnym i swoich potomków zachować między sobą pokój, nie przelewać z powodów religijnych krwi, nie karać się wzajemnie infamią, więzieniem. Książka Janusza Tazbira miała ogromny wpływ i niepodważalny udział w decyzji o umieszczeniu konfederacji warszawskiej na liście światowego programu UNESCO „Pamięć świata” 14.

Podążając drogą edycji Prac wybranych, przypomnieć wypadnie książkę Okrucieństwo w nowożytnej Europie. Autor, jak zawsze omawia w niej zagadnienia na szerokim tle historycznym i komparatystycznym. Prześladowania na tle wyznaniowym czy światopoglądowym, w rodzinie, wobec zwierząt - to tylko niektóre fragmenty książki opowiadającej o mrocznych stronach ludzkich charakterów. Podkreślił Autor, iż były okresy, w których mnożyły się okrucieństwa, to jednak zjawisko to wymyka się łatwym ocenom kwantytatywnym. Wszystkie szacunki liczbowe są na ogół przybliżone, tak gdy chodzi o ofiary polowań na czarownice, jak i ludzi skazywanych za przestępstwa kryminalne w XVI czy XVII wieku. Profesor Tazbir sporo miejsca

13 S. Grzybowski, dz. cyt., s. XIV.

14 Certyfikat wpisu wystawiono 16 października 2003 roku; 22 stycznia 2004 odbyła się na Zamku Królewskim w Warszawie uroczysta sesja z okazji wpisania aktu konfederacji do rejestru UNESCO „Memory of the World”. 
poświęcił problemowi tak zwanego przyzwolenia społecznego akceptacji różnych rodzajów okrucieństwa i nawiązał do wielu współczesnych problemów społecznych.

W kolejnym tomie Sarmaci $i$ świat Profesor podejmuje temat stosunku szlachty Rzeczypospolitej do konkwistadorów, opinii staropolskiej wobec podboju Ameryki przez Hiszpanię. Druga część tej książki jest poświęcona słowiańskim źródłom polskiej reformacji, Niemcom w polskim ruchu reformacyjnym, orientowi w kulturze sarmackiej, wpływom kultury włoskiej, kształtowaniu się stereotypów i innym tematom. Należy tu przypomnieć, iż odkrycia geograficzne i rozwój reformacji w Europie znalazły swoje miejsce w polemikach wyznaniowych toczonych w epoce Marcina Białobrzeskiego, Stanisława Sokołowskiego czy Marcina Kromera.

Kwestie wyznaniowe znalazły miejsce także $w$ wielu innych pracach Profesora Tazbira, dla przykładu: Kult św. Izydora w XVII i XVIII wieku, Obraz heretyka i diabla w propagandzie wyznaniowej XVI-XVII w. i inne.

Studia nad kultura staropolskq zawiera tom czwarty zebranych dzieł Janusza Tazbira i jest poświęcony zagadnieniom, które od początku kariery naukowej zajmowały Profesora. Autor w wielu innych pracach, nie pomieszczonych w powyżej wymienionym tomie, poświęcił uwagę wszechstronnemu oglądowi tamtego świata, którego relikty przetrwały do dziś. Sarmatyzm i barok europejski, który współbrzmiał właśnie dzięki kulturze I Rzeczypospolitej, która była w epoce nowożytnej niewątpliwym pośrednikiem między łacińskim Zachodem a bizantyjskim Wschodem, kumulując wszystkie te pierwiastki. Dlatego też wielu uczonych na świecie korzysta z powodzeniem ze spuścizny Profesora Tazbira. Wymienić wypadnie choćby takie nazwiska, jak Frank Sysyn, Dawid Frick, Luigi Marinelli, Giovanna Brogi Bercoff, Natalia Jakowenko, Walentyna Sobol i wielu innych.

Profesor Tazbir przy całym widocznym na każdej niemal stronicy sympatii do polskiego sarmatyzmu, nie szczędzi słów krytyki, gdy pisze o jego konserwatyzmie, wadach społecznych, politycznych i kulturowych, które w pewnym momencie miały kolosalny wpływ na upadek naszego państwa w końcu XVIII stulecia.

W nawiązaniu do badań Aleksandra Brücknera nad początkiem i rozwojem języka polskiego Janusz Tazbir podkreślał, że w XVII wieku nastąpiło największe oddziaływanie naszego języka, nie tylko w granicach państwowości szlacheckiej Rzeczypospolitej Obojga Narodów, lecz także większej liczby nacji ją zamieszkującej. Za zjawiskiem przejmowania polskiej mowy, szły obyczaje, kultura, a nawet tradycja historyczna. W drugiej połowie XVII wieku, język polski stal się najpopularniejszym językiem słowiańskim. Nie był to 
jedynie język „podboju” z okresu Dymitra Samozwańca, ale język komunikacji społecznej, cywilizacyjnej Moskwy. To prawda, że do czasów Piotra Wielkiego - jak to określił Janusz Tazbir - „byliśmy jednym z okien Rosji na świat" 15.

W tomie piątym wybranych prac Profesora znalazły się szkice o literaturze i sztuce. Sporą część stanowią prace wcześniej publikowane, ale $\mathrm{w}$ wersjach zmienionych i poszerzonych. Ich różnorodna tematyka od tytułu Rabelais wśród Polaków po Lektury naszych przodków, ukazuje znakomicie ogromny temperament intelektualny Autora, który nie pozostawał nigdy obojętny na otaczającą rzeczywistość. Można tu powtórzyć z całym przekonaniem za Fernandem Braudelem, że „historia jest po stronie życia, jest samym życiem”, że nie istnieje jakaś czarna linia, która oddziela przeszłość od teraźniejszości ${ }^{16}$.

„Długie trwanie" widać w twórczości Profesora Tazbira, ukazane w wielu perspektywach i barwach. Najbardziej uwidaczniają się, jak uważam, te charakterystyczne cechy „Tazbirowskiego trwania” w publikacjach: Prawdy $i$ zmyślenia w "Ogniem i mieczem” oraz Dzieje narodowe Biblii („Biblią narodową" nazwał Trylogię Paweł Jasienica).

Janusz Tazbir, mimo obiektywnego i wszechstronnego spojrzenia (bardzo ciekawe są rozważania na temat antemurale christianitas, perspektywy ukraińskiej i litewskiej, pararele francuskich i angielskich powieści historycznych), nie był w stanie ukryć własnych sympatii. Sam zresztą przyznał, że od pół wieku powraca chętnie do lektury Potopu. Nie dziwi więc fakt, iż esej Dzieje narodowej Biblii w skróconej wersji stał się jednym z tekstów, którego analizy mieli dokonać maturzyści zdający egzamin z języka polskiego w 1999 roku.

Wypadnie jeszcze zwrócić uwagę przynajmniej na jeszcze jeden esej Powieść historyczna odbiciem wspótczesności zamieszczona w cytowanym piątym tomie. Profesor zwykł mawiać, że każde pokolenie pisze własną wersję historii, choć zdaje się, nie jest to spojrzenie pesymisty. Współczesny historyk może po prostu zadać źródłom inne pytania, aniżeli jego kolega zadawał sto lat wcześniej.

Lektura prac Profesora Tazbira nasuwa wiele refleksji nad historią Rzeczypospolitej, ale też nad jej współczesnością, nad losami narodu i państwa, a także poszczególnych jej członków, nad zjawiskami, które często nie przemijają, lecz zmieniają jedynie swe oblicze. Rodzą się również pytania o dal-

15 J. Tazbir, Prace wybrane, t. IV, s. 287.

16 F. Braudel, Historia i trwanie, Warszawa 1971, s. 336. 
szą drogę humanisty, który niestety jakże często ucieka w swych badaniach przed porównaniami, zamyka się $\mathrm{w}$ wąskich tematach, czyni poszukiwania źródłowe, by potem dosłownie zdać z nich jedynie relacje. Powstają książki - vademeca, do których się sięga jedynie w celu sprawdzenia wiadomości. Twórczość Profesora Janusza Tazbira nawiązuje do bogatej tradycji polskiej historiografii, którą czytano i dyskutowano - nie tylko w "klubach dziesięciu wtajemniczonych".

Profesor zwierzał się przy wielu okazjach, iż jego marzeniem byłoby wejście na powrót, jak to zwykł określać, literatury pięknej w związki z historią i że znajdą się tacy jej „kapłani”, jak kiedyś Szajnocha, Kubala czy Brückner. Trzeba do tej listy, o czym jestem przekonana dopisać także nazwisko Janusza Tazbira, którego styl, klarowność myśli przelewanej na papier, przysłowiowa lekkość pióra zjednała Mu grono wielu czytelników a także słuchaczy. Profesor był znakomitym popularyzatorem, jego audycje radiowe i telewizyjne cieszyły się ogromna popularnością, dość wspomnieć telewizyjną audycję w cyklu Rozmowy na koniec wieku.

Ostatnią pozycją książkową pod redakcją Profesora jest praca zbiorowa Z szabla i kielichem czyli życie po sarmacku, która ukazała się w końcu 2015 roku w Oficynie Wydawniczej „Stopka” (Łomża 2015).

Zacytujmy jeszcze na koniec fragment eseju na temat tradycji I Rzeczypospolitej, której tak wielkim był Profesor admiratorem, aczkolwiek nie pozbawionym krytycznego także spojrzenia:

Trudno [...] zaprzeczyć, że w XVI stuleciu oraz $\mathrm{w}$ pierwszej połowie następnego „wielka konfrontacja” kultur, tradycji historycznych i wyznań przebiegała w Polsce pod znakiem kompromisu oraz unikania skrajności: dwóch cech tak charakterystycznych dla dziejów naszej kultury, w tym również politycznej. Szeroko pojmowana tolerancja, owo poszanowanie dla czyjejś odrębności nie tylko etnicznej lub wyznaniowej, ale również w zakresie obyczaju i kultury, służyła nie tylko mniejszości, która owa odrębność reprezentowała. Wzbogacała także kulturę ludzi, którzy te tolerancję okazywali, a więc naszych przodków, obywateli I Rzeczypospolitej ${ }^{17}$.

Profesor Janusz Tazbir był wielokrotnie odznaczany i wyróżniany: Krzyżem Komandorskim z Gwiazdą Orderu Odrodzenia Polski w uznaniu wybitnych zasług dla rozwoju nauki (1999), Krzyżem Komandorskim Odrodzenia Polski (1992), Krzyżem Kawalerskim Orderu Odrodzenia Polski (1978) Medalem Komisji Edukacji Narodowej, Złotym Medalem Zasłużony Kulturze

17 J. Tazbir, Tradycje wieloetnicznej Rzeczypospolitej, [w:] Inni wśród swoich, red. W. Władyka, Warszawa 1994, s. 23. 
Gloria Artis (2008) oraz tytułami doktora honoris causa Uniwersytetu Opolskiego w 2000 roku, Rosyjskiej Akademii Nauk w 2008 roku a także nagrodą Fundacji Alfreda Jurzykowskiego w 1988 roku (USA).

Dla nas, historyków z Uniwersytetu w Białymstoku był postacią bardzo ważną, przy wielu okazjach wyrażał swoją sympatię i uznanie dla naszego środowiska, z sentymentem podkreślał swe związki rodzinne i wspominał czasy młodości związane ze wschodnimi terenami Polski.

Pozostawił małżonkę, Panią doktor Julię Tazbirową, historyka, córkę Aldonę, dwójkę wnuków i czwórkę prawnuków. Opuścił przyjaciól, kolegów i uczniów. Ja, straciłam mego ostatniego Mistrza, któremu wiele zawdzięczam.

Nam wszystkim będzie Go bardzo brakowało.

Teresa Chynczewska-Hennel, historyk, prof. dr hab., pracuje w Instytucie Historii i Nauk Politycznych Uniwersytetu w Białymstoku.

e-mail: bartok2@gazeta.pl 